\title{
The potential role of inhaled nitric oxide for postexposure chemoprophylaxis of COVID- 19
}

\author{
Antoine AbdelMassih ${ }^{1,2^{*}}$ (D) Rafeef Hozaien ${ }^{3}$, Meryam El Shershaby ${ }^{3}$, Aya Kamel ${ }^{3}$, Habiba-Allah Ismail ${ }^{3}$, \\ Mariem Arsanyous ${ }^{3}$, Nadine El-Husseiny ${ }^{4,5}$, Noha Khalii ${ }^{3}$, Youstina Naeem ${ }^{3}$ and Raghda Fouda ${ }^{6}$
}

\begin{abstract}
Background: Several vaccines have been fast-tracked in an attempt to decrease the morbidity and mortality of COVID-19. However, post-exposure prophylaxis has been overlooked in battling COVID-19.

Main text: Inhaled nitric oxide is a potential tool in post-exposure prophylaxis of COVID-19. It decreases cytosolic calcium levels, which impairs the action of Furin. SARS-CoV-2 uses Furin to replicate in the respiratory tract.

Short conclusion: Inhaled nitric oxide could decrease the viral load in the upper respiratory tract, abort clinically symptomatic infection, and prevent subsequent complications. Nitric oxide might be a tool for post-exposure chemoprophylaxis in at-risk groups, especially medical personnel.
\end{abstract}

\section{Background}

SaNOtize (Canada, Vancouver-based/NCT04443868 biotech firm) recently created a self-administered nitric oxide nasal spray (NONS) that could potentially reduce coronavirus disease 2019 (COVID-19) viral load in infected patients. After completing early-stage clinical trials in Canada and the United Kingdom (UK), SaNOtize, Ashford and St. Peter's Hospitals, the National Hospital System (NHS) foundation, and a few pathology services in the UK announced the results of phase II trials. The results indicate that NONS can be a powerful and safe antiviral treatment. It could prevent COVID-19 transmission, shorten its duration, and reduce the severity of its symptoms.

Some reports have discussed the use of nitric oxide against COVID-19. Lotz et al., for example, highlighted its potential to improve acute respiratory distress syndrome in COVID-19.

\footnotetext{
* Correspondence: antoine.abdelmassih@kasralainy.edu.eg

${ }^{1}$ Pediatric Cardiology unit, Pediatrics' Department, Faculty of Medicine, Cairo

University, Cairo, Egypt

${ }^{2}$ Pediatric Cardio-Oncology Department, Children Cancer Hospital of Egypt,

Cairo 57357, Egypt

Full list of author information is available at the end of the article
}

However, SaNOtize's clinical trial results suggest that it has a much earlier antiviral role against COVID-19. We will discuss the exact mechanism behind this in this report [1].

\section{Main text \\ Protease is critical to determine the viral load of COVID- 19}

Furin is a member of the PCSK (pro-protein convertase subtilizing/Kexin) family. Furin is a type 1 membrane-bound protease utilized by multiple pathogens including human immune deficiency virus (HIV), Ebola virus, Marburg virus, severe acute respiratory syndrome coronavirus 2 (SARS-CoV2 ), and even some bacterial toxins. Pathogenicity can increase several folds once they react with Furin and other pro-protein convertases. After Furin is cleaved, latent precursor proteins are activated. Hence, Furin-dependent infections may respond to therapeutics targeting host cell Furin [2].

The spike protein of SARS-CoV-2 is the cleavage site of Furin. It plays an essential role in the pathogenesis, host range, and infectivity of the virus. Furin requires a polybasic instead of a monobasic cleavage site. Hence, cleavage occurs at the junction of the two polybasic, spike protein subunits (S1 and S2). High virulence and

\section{Springer Open}

(c) The Author(s). 2021 Open Access This article is licensed under a Creative Commons Attribution 4.0 International License, which permits use, sharing, adaptation, distribution and reproduction in any medium or format, as long as you give appropriate credit to the original author(s) and the source, provide a link to the Creative Commons licence, and indicate if changes were made. The images or other third party material in this article are included in the article's Creative Commons licence, unless indicated otherwise in a credit line to the material. If material is not included in the article's Creative Commons licence and your intended use is not permitted by statutory regulation or exceeds the permitted use, you will need to obtain permission directly from the copyright holder. To view a copy of this licence, visit http://creativecommons.org/licenses/by/4.0/. 
Table 1 Review of in vivo and in vitro studies of the antiviral effect of nitric oxide

\begin{tabular}{lll}
\hline $\begin{array}{l}\text { Reference Virus } \\
\text { number in }\end{array}$ & $\begin{array}{l}\text { Type of nitric oxide Study model } \\
\text { therapy }\end{array}$ & Main outcome \\
text & &
\end{tabular}

\begin{tabular}{|c|c|c|c|}
\hline \multirow[t]{2}{*}[4,5]{} & SARS-CoV & NO donor, SNAP & In vitro \\
\hline & & $\begin{array}{l}\text { NO donors, SNAP } \\
\text { and SNP }\end{array}$ & In vitro \\
\hline$[7,8]$ & SARS-CoV-2 & inhaled NO & $\begin{array}{l}\text { Multicenter randomized } \\
\text { controlled trial }\end{array}$ \\
\hline
\end{tabular}

Inhibited SARS CoV replication cycle in a concentrationdependent manner (1)

SNAP and SNP inhibited the SARS CoV viral cytopathic effect (2) controlled tria

Ongoing, antiviral effect of high concentrations of inhaled NO administered during early phases of COVID-19 on spontaneous breathing patients, effect on disease progression (3)

Ongoing, testing inhaled Nitric Oxide in mechanically ventilated patients with severe acute respiratory syndrome in COVID-19 (SARS-CoV-2) (4)

Single-center, randomized Ongoing, prophylactic therapy to reduce the instance of (1:1) controlled, parallel-arm COVID-19 disease in healthcare workers (4) clinical trial

SNAP In vitro

[9] Coxsackievirus

NO donors SNAP

In vitro

Murine model

iNO, SNAP

NO donors

SNAP, PFC, GTN,

ISDN)

$[10,11] \quad$ Influenza

Gaseous nitric oxide In vitro (gNO)

SNAP

[12]

Japanese SNAP encephalitis virus (JEV)

In vitro

MDF to produce NO (inducible NO)

Nitric oxide donor In vitro (NONOate)

Herpes simplex virus type 1 (HSV 1) Porcine circovirus type 2 (PCV2)

NO generated from (GSNO)

iNO

In vitro

Crimean Congo

SNAP hemorrhagic fever virus (CCHFV)

SNAP

In vitro Respiratory
Syncytial Virus (RSV)

Human papillomaviruses (HPVs)

iNO, SNAP

Vesicular stomatitis virus (VSV)

NVN1000, Topical

NO-releasing polymer

In vivo, in vitro (Murine model)

In vitro

iNO, SNAP

In vitro

Molluscum

Topical acidified
SNAP delayed or completely prevented the development of viral cytopathic effect (5)

NO inhibits CVB3 replication by inhibiting protease activity and interrupting the viral life cycle (6)

NO inhibits CVB3 replication in part by inhibiting viral RNA and protein synthesis (7)

In vitro NO showed inhibition of the $2 \mathrm{~A}$ proteinase activity CVB3-infected mice showed significantly reduced signs of myocarditis after treatment with GTN or ISDN (8)

Viral NA inhibition by gNO was shown and may be responsible for this antiviral effect (9)

inhibition of influenza virus viral RNA synthesis (10)

NO was found to profoundly inhibit viral RNA synthesis, viral protein accumulation, and virus release from infected cells (11)

MDF stimulated macrophages inhibited virus replication with high levels of NO production. MDF treatment increased the survival rate of JEV infected mice (12)

(NONOate) inhibited both rhinovirus replication and cytokine production in a dose-dependent fashion without reducing levels of cytokine mRNA (13)

Cytostatic effects antiviral effects e.g. reduction in DNA synthesis, protein synthesis \& mitochondrial metabolism (14)

NO showed an inhibitory effect on viral RNA synthesis. The activity of the viral replicase was suppressed significantly (15)

Nitric oxide had inhibitory effects on HSV1 protein and DNA synthesis as well as on cell replication (16)

NO strongly inhibited PCV2 replication in vitro. NO reduced the progression of PCV2 infection in mice (17)

NO reduced virion progeny yield with a reduction in expression of viral proteins; the nucleocapsid protein and the glycoprotein, and vRNA (18)

NO has significant direct antiviral activity against RSV, which is more potent with continuous, endogenous NO production than exogenous NO (19)

NO abrogated HPV-18 progeny virus production. Reduced HPV-18 E6 and E7 oncoproteins. Impaired S-phase progression and induced DNA damage in infected cultures (20) anti-VSV effects of NO in form of significant inhibition of productive VSV infection (21)

$75 \%$ cure rate in the active treatment group 
Table 1 Review of in vivo and in vitro studies of the antiviral effect of nitric oxide (Continued)

\begin{tabular}{|c|c|c|c|c|}
\hline $\begin{array}{l}\text { Reference } \\
\text { number in } \\
\text { text }\end{array}$ & Virus & $\begin{array}{l}\text { Type of nitric oxide } \\
\text { therapy }\end{array}$ & Study model & Main outcome \\
\hline & contagiosum & $\begin{array}{l}\text { nitrite, nitric oxide } \\
\text { liberating cream) }\end{array}$ & sequential clinical trial & $\begin{array}{l}\mathrm{NO} \text { is an effective therapy with a } 75 \% \text { cure rate in the } \\
\text { treatment group compared to } 21 \% \text { in the control group (22) }\end{array}$ \\
\hline & & $\begin{array}{l}\text { topical SB206 (NO } \\
\text { releasing topical gel) }\end{array}$ & $\begin{array}{l}\text { multicenter, randomized, } \\
\text { double-blind, vehicle- } \\
\text { controlled clinical trial }\end{array}$ & $\begin{array}{l}\text { SB206 is an effective therapy with (SB206 12\% / once daily) } \\
\text { provided the best balance between MC lesion clearance and } \\
\text { tolerability (22) }\end{array}$ \\
\hline$[6]$ & Hantavirus & iNO, SNAP & In vitro, murine model & $\begin{array}{l}\text { NO strongly inhibited hantavirus replication in vitro. The viral } \\
\text { titers in iNOS }{ }^{-1} \text { mice were higher compared to the controls, } \\
\text { suggesting that NO inhibits hantavirus replication in vivo (23) }\end{array}$ \\
\hline
\end{tabular}

Abbreviations: NO nirtic oxide, SNAP S-nitroso-N-acetylpenicillamine, GTN glyceryl trinitrate, ISDN isosorbide dinitrate, PFC: 4-phenyl-3-furoxancarbonitrile, iNO inducible NO, CVB3 coxsackievirus B3, gNO gaseous nitric oxide, NA neuraminidase, JEV Japanese encephalitis virus, MDF macrophage-derived neutrophil chemotactic factor, NONOate 3-(2-hydroxy-2-nitroso-1-propylhydrazino)-1-propanamine, HSV1 herpes simplex virus type 1, DENV dengue virus, PCV2 porcine circovirus type 2, GSNO S-nitrosoglutathione, CCHFV Crimean Congo hemorrhagic fever virus, RSV respiratory syncytial virus, VSV vesicular stomatitis virus

low virulence influenza strains have different pathogenicities and are an excellent example of the relationship between viral pathogenicity and cleavage sites [3].

\section{Nitric oxide is an inhibitor of viral proteases and subsequently of viral replication}

Previous studies have noted that the antiviral role of nitric oxide is due to its inhibition of viral protease activity. It also prohibits viral replication. In a study, several viruses demonstrated the mechanism behind this phenomenon. These included coxsackievirus, picornaviruses, hantavirus, herpesvirus, rhinovirus, Japanese encephalitis, vaccinia, retrovirus, and many more (Table 1 exposes the clinical and laboratory trials which used NO as an antiviral agent) [4-24].

\section{Nitric oxide inhibits viral protease activity by decreasing intracellular cations}

Furin is a cellular protease enzyme expressed from the FURIN gene in humans. Furin shows an intriguing interplay between intracellular ions, especially cations. Potassium ions are the most common intracellular ions in our bodies, followed by magnesium-which can activate Furin directly. Molloy et al. noted that the intracellular calcium level noticeably influences the activity of Furin. Thus, Furin is a calcium-dependent enzyme [25].

Yamada and colleagues further supported the relationship between Furin and calcium levels. Inhibiting Furin prevented further neuronal damage caused by calcium influx after hypoxic injury [26]. Hence, impeding calcium channels can be a promising approach against Furin-activated organisms. Additionally, Li et al. stated in 2019 that calcium channel blockers (CCB) decrease the intensity of fever spikes and the occurrence of thrombocytopenia syndrome, categorized by manifestations of tick-borne hemorrhagic fever [27].

Nitric oxide encourages calcium efflux from cells, leading to decreased intracellular calcium levels. Van Hove et al. demonstrated this and proved that nitric oxide stimulates smooth muscle cells (SMCs) to relax directly or indirectly by decreasing the elevated calcium level [28]. As such, nitric oxide could inhibit Furin's action by decreasing cytosolic levels of calcium.

\section{Inhaled nitric oxide as post-exposure prophylaxis}

Argyropoulos et al. concluded that a diagnostic viral load has no prognostic value [29]. While in a more recent report, Silva et al. found the saliva viral loads to be significantly higher in patients with chronic respiratory conditions, cardiovascular conditions, kidney disease, and diseases that compromise the immune system [30]. Patients with four or more risk factors had much higher saliva viral loads than patients with fewer risk factors, as did male patients. However, there was no relation between nose and throat viral loads and risk factors. Saliva viral loads were also higher in patients with worse clinical outcomes. As such, early interruption of viral replication in the upper respiratory tract might abort the development of significant symptoms and complications. This rationale might have led to the current inclusion criteria of SaNOtize's ongoing clinical trial, which involves administration of the intranasal medication within $48 \mathrm{~h}$ of a diagnosis. SaNOtize could potentially be administered to medical personnel as post-exposure chemoprophylaxis.

\section{Conclusion}

Early reports of the role of nitric oxide in the treatment of COVID-19 suggested its use for the treatment of established acute respiratory distress syndrome. However, nitric oxide seems to have a much earlier and more efficient prophylactic role. It inhibits Furin, a protease needed for canonical viral replication of SARS-CoV-2, by decreasing cytosolic calcium levels. This action can prevent the exponential increase of viral load in the upper respiratory tract leading to the abortion of 


\section{INHALED NO FOR CHEMOPROPHYLAXIS OF COVID19}

\section{SaNOtize (Inhaled NO)}

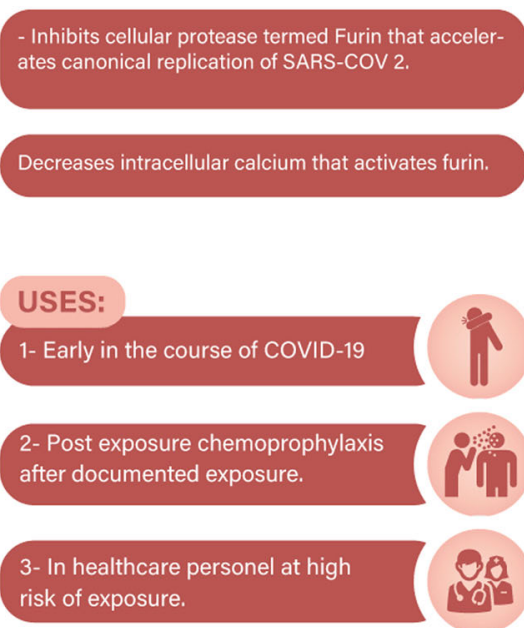

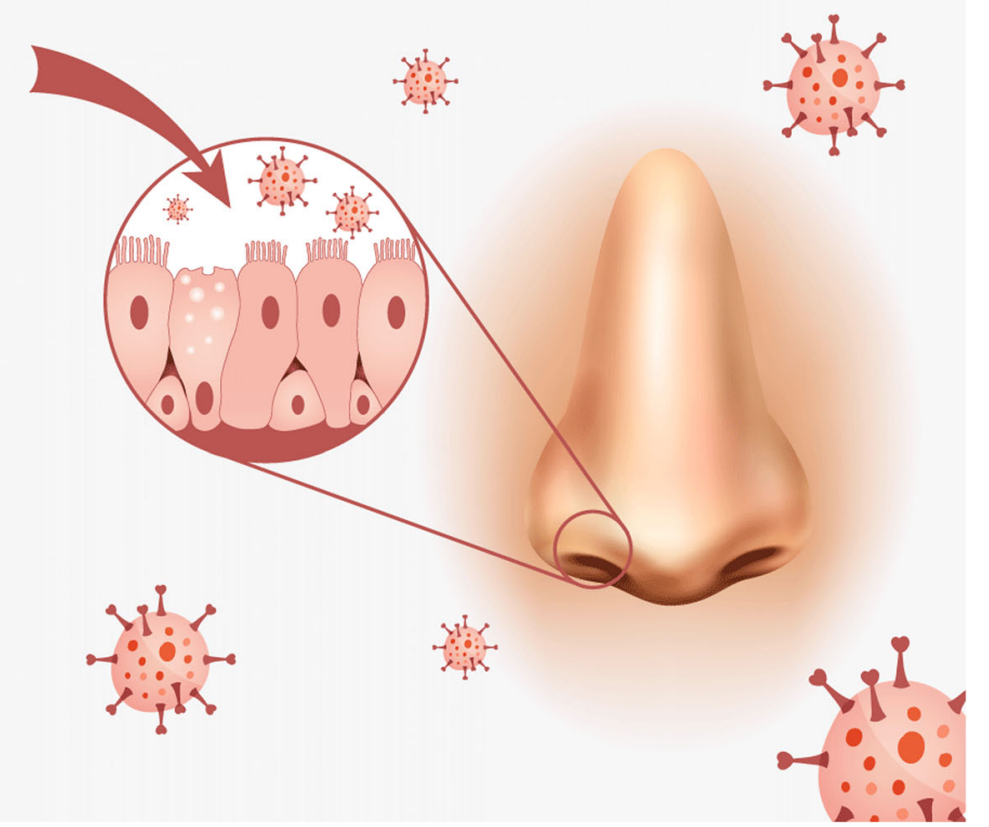

Fig. 1 Inhaled NO for chemoprophylaxis of COVID-19. Abbreviations: COVID-19, coronavirus 2019; NO, nitric oxide; SARS-CoV-2, severe acute respiratory syndrome coronavirus 2

clinically symptomatic infection and subsequent complications. Nitric oxide could be a tool for post-exposure chemoprophylaxis in the at-risk groups, especially medical personnel.

Figure 1 summarizes the antiviral effect of nitric oxide and its possible uses in the context of COVID-19.

\section{Abbreviations}

CCB: Calcium channel blocker; COVID-19: Coronavirus 2019; NHS: National Hospital System; NO: Nitric oxide; NONS: Nitric oxide nasal spray; SARS-CoV2: Severe acute respiratory syndrome coronavirus 2; UK: United Kingdom

\section{Acknowledgements}

To our families who are bearing the weight of our sacrifice of time to our patients. If our families were not understanding to the depth of our struggle, we would have never been able to keep the same level of dedication to our patients. To our students that we involve in each step of our researches to make them flourish in this field and take the lead the soonest the possible.

\section{Authors' contributions}

$\mathrm{AA}, \mathrm{HI}, \mathrm{AK}$, and $\mathrm{ME}$ contributed to the conception and design of the work. $R F, Y N, R H, M A, N E$, and NK contributed significantly to the acquisition of data. $A A, H I, A K, M E, R F, Y N, R H, M A, N E$, and $N K$ contributed to the analysis and interpretation of data. $A A, H I, A K, M E, R F, Y N, R H, M A, N E$, and $N K$ contributed to the drafting and revision of the manuscript. All authors have approved the submitted version. All authors have agreed both to be personally accountable for the author's own contributions and to ensure that questions related to the accuracy or integrity of any part of the work, even ones in which the author was not personally involved, are appropriately investigated, resolved, and the resolution documented in the literature.

\section{Funding}

This research received no specific grant from any funding agency, commercial or not-for-profit sectors.

\section{Availability of data and materials}

Not applicable

\section{Declarations}

Ethics approval and consent to participate

Not applicable.

\section{Consent for publication}

Not applicable.

\section{Competing interests}

The authors declare that they have no competing interests.

\section{Author details}

${ }^{1}$ Pediatric Cardiology unit, Pediatrics' Department, Faculty of Medicine, Cairo University, Cairo, Egypt. ${ }^{2}$ Pediatric Cardio-Oncology Department, Children Cancer Hospital of Egypt, Cairo 57357, Egypt. ${ }^{3}$ Research Accessibility Team, Student and Internship research program Faculty of Medicine, Cairo University, Cairo, Egypt. ${ }^{4}$ Faculty of Dentistry, Cairo University, Cairo, Egypt. ${ }^{5}$ Pixagon Graphic Design Agency, Cairo, Egypt. ${ }^{6} \mathrm{Clinical}$ and Chemical Pathology Department, Faculty of Medicine, Cairo University, Cairo, Egypt.

Received: 29 June 2021 Accepted: 24 September 2021

Published online: 22 October 2021

\section{References}

1. Lotz C, Muellenbach RM, Meybohm P, Mutlak H, Lepper PM, Rolfes C, Peivandi A, Stumpner J, Kredel M, Kranke P, Torje I, Reyher C (2021) Effects of inhaled nitric oxide in COVID-19-induced ARDS - Is it worthwhile? Acta 
Anaesthesiol Scand 65(5):629-632. Available from: doi. https://doi.org/ $0.1111 /$ aas. 13757

2. AbdelMassih AF, Ye J, Kamel A, Mishriky F, Ismail HA, Ragab HA, El Qadi L, Malak L, Abdu M, El-Husseiny M, Ashraf M, Hafez N, AlShehry N, El Husseiny N, AbdelRaouf N, Shebl N, Hafez N, Youssef N, Afdal P, Hozaien R, Menshawey R, Saeed R, Fouda R (2020) A multicenter consensus: a role of furin in the endothelial tropism in obese patients with COVID-19 infection. Obes Med 19:100281. https://doi.org/10.1016/j.obmed.2020.100281

3. Hoffmann M, Kleine-Weber H, Schroeder S, Kruger N, Herrler T, Erichsen S, Schiergens TS, Herrler G, Wu N-H, Nitsche A, Muller MA, Drosten C, Pohlmann S (2020) SARS-CoV-2 cell entry depends on ACE2 and TMPRSS2 and is blocked by a clinically proven protease inhibitor. Cell 181(2):271-280. e8

4. Akerstrom S, Mousavi-Jazi M, Klingström J, Leijon M, Lundkvist A, Mirazimi A. 2005 Nitric oxide inhibits the replication cycle of severe acute respiratory syndrome coronavirus. J Virol 79(3):1966-69. Available from: https://doi. org/10.1128/JVI.79.3.1966-1969.2005

5. Keyaerts E, Vijgen L, Chen L, Maes P, Hedenstierna G, Van Ranst M (2004) Inhibition of SARS-coronavirus infection in vitro by S-nitroso-Nacetylpenicillamine, a nitric oxide donor compound. Int J Infect Dis 8(4): 223-226. Available from: https://linkinghub.elsevier.com/retrieve/pii/S1201 971204000529. https://doi.org/10.1016/j.ijid.2004.04.012

6. Klingstrom J, Akerstrom S, Hardestam J, Stoltz M, Simon M, Falk KI, Mirazimi A, Rottenberg M, Lundkvist A. 2006 Nitric oxide and peroxynitrite have different antiviral effects against hantavirus replication and free mature virions. Eur J Immunol 36(10):2649-57. Available from: https://doi.org/10.1 002/eji.200535587

7. Lei C, Su B, Dong H, Bellavia A, Di Fenza R, Fakhr BS, Gianni S, Grassi LG, Pinciroli R, Vassena E, Berra L. 2020 Protocol of a randomized controlled trial testing inhaled Nitric Oxide in mechanically ventilated patients with severe acute respiratory syndrome in COVID-19 (SARS-CoV-2). medRxiv Prepr Serv Health Sci. Preprint at https://doi.org/10.1101/2020.03.09.20033530

8. Akaberi D, Krambrich J, Ling J, Luni C, Hedenstierna G, Jarhult JD, Lennerstrand J, Lundkvist A (2020) Mitigation of the replication of SARSCoV-2 by nitric oxide in vitro. Redox Biol 37:101734 Available from: https:// linkinghub.elsevier.com/retrieve/pii/S2213231720309393

9. Zell R, Markgraf R, Schmidtke M, Gorlach M, Stelzner A, Henke A, Sigusch HH, Glck B. 2004 Nitric oxide donors inhibit the coxsackievirus B3 proteinases $2 \mathrm{~A}$ and $3 \mathrm{C}$ in vitro, virus production in cells, and signs of myocarditis in virus-infected mice. Med Microbiol Immunol;193(2-3):91-100. Available from: https://doi.org/10.1007/s00430-003-0198-6

10. Regev-Shoshani G, Vimalanathan S, McMullin B, Road J, Av-Gay Y, Miller C Gaseous nitric oxide reduces influenza infectivity in vitro. Nitric oxide Biol Chem 31:48-53 Available from: http://www.ncbi.nlm.nih.gov/pubmed/23562 771

11. Rimmelzwaan GF, Baars MM, de Lijster P, Fouchier RA, Osterhaus AD (1999) Inhibition of influenza virus replication by nitric oxide. J Virol 73(10):88808883 Available from: http://www.ncbi.nlm.nih.gov/pubmed/10482647

12. Lin YL, Huang YL, Ma SH, Yeh CT, Chiou SY, Chen LK, Liao CL (1997) Inhibition of Japanese encephalitis virus infection by nitric oxide: antiviral effect of nitric oxide on RNA virus replication. J Virol 71(7):5227-5235 Available from: http://www.ncbi.nlm.nih.gov/pubmed/9188590

13. Banerjee NS, Moore DW, Wang HK, Broker TR, Chow LT (2019) NVN1000, a novel nitric oxide-releasing compound, inhibits HPV-18 virus production by interfering with E6 and E7 oncoprotein functions. Antiviral Res 170:104559 Available from: http://www.ncbi.n/m.nih.gov/pubmed/104559

14. Tang DJ, Xu YH, Dai D, Han YJ, Wang BC, Lang YM, Liang Y, Zeng Y (1989) Clinical analysis of four Chinese hemophiliacs with human immunodeficiency virus infection. Chin Med J 102(11):819-824 Available from: http://www.ncbi.nlm.nih.gov/pubmed/2517721

15. Takhampunya R, Padmanabhan R, Ubol S. 2006 Antiviral action of nitric oxide on dengue virus type 2 replication. J Gen Virol 87(10):3003-11. Available from: https://doi.org/10.1099/vir.0.81880-0

16. Croen KD (1993) Evidence for antiviral effect of nitric oxide. Inhibition of herpes simplex virus type 1 replication. J Clin Invest 91(6):2446-2452 Available from: http://www.ncbi.nlm.nih.gov/pubmed/8390481

17. Saura M, Zaragoza C, McMillan A, Quick RA, Hohenadl C, Lowenstein JM, Lowenstein CJ (1999) An antiviral mechanism of nitric oxide. Immunity 10(1):21-28. Available from: https://linkinghub.elsevier.com/retrieve/pii/S1 074761300800035. https://doi.org/10.1016/\$1074-7613(00)80003-5
18. Simon M, Falk Kl, Lundkvist A, Mirazimi A (2006) Exogenous nitric oxide inhibits Crimean Congo hemorrhagic fever virus. Virus Res 120(1-2):184190. Available from: https://linkinghub.elsevier.com/retrieve/pii/S01681702 0600092X. https://doi.org/10.1016/j.virusres.2006.03.005

19. Domachowske JB. 2003 Replication of respiratory syncytial virus is inhibited in target cells generating nitric oxide in situ. Front Biosci 8(1):986. Available from: https://doi.org/10.2741/986

20. Bi Z, Reiss CS (1995) Inhibition of vesicular stomatitis virus infection by nitric oxide. J Virol 69(4):2208-2213. https://doi.org/10.1128/jvi.69.4.2208-2213.1995

21. Ormerod AD, White MI, Shah SA, Benjamin N (1999) Molluscum contagiosum effectively treated with a topical acidified nitrite, nitric oxide liberating cream. Br J Dermatol 141(6):1051-1053 Available from: http:// www.ncbi.nlm.nih.gov/pubmed/10606851

22. Sanders SP, Siekierski ES, Porter JD, Richards SM, Proud D (1998) Nitric oxide inhibits rhinovirus-induced cytokine production and viral replication in a human respiratory epithelial cell line. J Virol 72(2):934-942 Available from: http://www.ncbi.nlm.nih.gov/pubmed/9444985

23. Griffon B, Cillard J, Chevanne M, Morel I, Cillard P, Sergent O. 1998 Macrophage-induced inhibition of nitric oxide production in primary rat hepatocyte cultures via prostaglandin E2 release. Hepatology 28(5):1300-08. Available from: https://doi.org/10.1002/hep.510280519

24. Lei C, Su B, Dong H, Fakhr BS, Grassi LG, Di Fenza R, Gianni S, Pinciroli R, Vassena E, Morais CCA, Bellavia A, Spina S, Kacmarek R, Berra L. 2020 Protocol for a randomized controlled trial testing inhaled nitric oxide therapy in spontaneously breathing patients with COVID-19. medRxiv Prepr Serv Health Sci. Preprint at https://doi.org/10.1101/2020.03.10.20033522

25. Molloy SS, Bresnahan PA, Leppla SH, Klimpel KR, Thomas G (1992) Human furin is a calcium-dependent serine endoprotease that recognizes the sequence Arg-X-X-Arg and efficiently cleaves anthrax toxin protective antigen. J Biol Chem 267(23):16396-16402. https://doi.org/10.1016/50021-92 58(18)42016-9

26. Yamada M, Hayashi H, Yuuki M, Matsushima N, Yuan B, Takagi N (2018) Furin inhibitor protects against neuronal cell death induced by activated NMDA receptors. Sci Rep 8(1):1-9

27. Li H, Zhang LK, Li SF, Zhang SF, Wan WW, Zhang YL, Xin QL, Dai K, Hu YY, Wang ZB, Zhu XT, Fang YJ, Cui N, Zhang PH, Yuan C, Lu Q, Bai JY, Deng F, Xiao GF, Liu W, Peng K. Calcium channel blockers reduce severe fever with thrombocytopenia syndrome virus (SFTSV) related fatality. Cell Res 2019; 29(9):739-753. Available from: https://doi.org/10.1038/s41422-019-0214-z

28. Van Hove CE, Van der Donckt C, Herman AG, Bult H, Fransen P (2009) Vasodilator efficacy of nitric oxide depends on mechanisms of intracellular calcium mobilization in mouse aortic smooth muscle cells. Br J Pharmacol 158(3):920-930 Available from: http://www.ncbi.nlm.nih.gov/pubmed/1 9788496

29. Argyropoulos KV, Serrano A, Hu J, Black M, Feng X, Shen G, Call M, Kim MJ, Lytle A, Belovarac B, Vougiouklakis T, Lin LH, Moran U, Heguy A, Troxel A, Snuderl M, Osman I, Cotzia P, Jour G (2020) Association of initial viral load in severe acute respiratory syndrome coronavirus 2 (SARS-CoV-2) patients with outcome and symptoms. Am J Pathol 190(9):1881-1887 Available from: https://linkinghub.elsevier.com/retrieve/pii/S000294402030328X

30. Silva J, Lucas C, Sundaram M, Israelow B, Wong P, Klein J, Tokuyama M, Lu P, Venkataraman A, Liu F, Mao T, Oh JE, Park A, Casanovas-Massana A, CBF V, Muenker CM, Zell J, Fournier JB, Campbell M, Chiorazzi M, Ruiz Fuentes E, Petrone M, Kalinich CC, Ott IM, Watkins A, Moore AJ, Nakahata MI, Grubaugh ND, Farhadian S, Dela Cruz C, Ko A, Schulz WL, Ring AM, Ma S, Omer S, Wyllie AL, Iwasaki A (2021) Saliva viral load is a dynamic unifying correlate of COVID-19 severity and mortality. medRxiv Prepr Serv Health Sci Available from: http://www.ncbi.n/m.nih.gov/pubmed/33442706

\section{Publisher's Note}

Springer Nature remains neutral with regard to jurisdictional claims in published maps and institutional affiliations. 